\title{
Assessing Sustainability Impact of Autonomous Haul System in Indonesian Open Pit Coal Mining Company
}

\author{
Yonta Wasfadhita \\ Master of Mechanical Engineering \\ Swiss German University \\ Tangerang City, Indonesia \\ yonta.wasfadhita@student.sgu.ac.id \\ Dena Hendriana \\ Master of Mechanical Engineering \\ Swiss German University \\ Tangerang City, Indonesia \\ dena.hendriana@sgu.ac.id
}

\author{
Gembong Baskoro \\ Master of Mechanical Engineering \\ Swiss German University \\ Tangerang City, Indonesia \\ gembong.baskoro@sgu.ac.id
}

\author{
Eka Budiarto \\ Master of Information Technology \\ Swiss German University \\ Tangerang City, Indonesia \\ eka.budiarto@sgu.ac.id \\ Henry Nasution \\ Master of Mechanical Engineering \\ Swiss German University \\ Tangerang City, Indonesia \\ henry.nasution@sgu.ac.id
}

\begin{abstract}
Autonomous Haul System (AHS) has been widely developed in the world since 2007. The main objective of AHS is to eliminate human factors, so that AHS productivity is much higher compared to manned dump trucks. The use of AHS in Indonesia will impact the sustainability index of open pit coal mines. Implementation AHS will affect with slightly higher sustainability index than manned haul trucks, AHS sustainability index is 78,712 and manned haul truck is 74,966. However, there are two sustainability dimensions when using AHS will go decrease, those dimensions are the social and economic dimensions, and AHS will be increasing sustainability index for Ecology, Legal dan Infrastructure Technology.
\end{abstract}

Keywords-open pit coal mine, productivity, manned dump truck, autonomous haul system, sustainability.

\section{INTRODUCTION}

Operator heavy equipment as of human in a mining operation must work in tight schedule, work in shift. Intense and monotonous work leads to fatigue, errors, and, as a result, to accidents. To eliminate "human factor" also allow to reduce unproductive downtime of equipment a heavy equipment manufactures purpose automation operation [1]. One of developed autonomous is haul truck, because autonomous haul truck has significant contribution to reduce and eliminate "human factor". AHS illustration as shown in Fig. 1.

AHS populations around the world starting in 2007 until 2020 has reached 396 units, with a wide variation of tonnage class, is operated not only in countries with difficulties searching for an operator such as Australia and developed by a world-class manufacturer of heavy equipment [2]. Indonesia, as a country that has a coal mining industry whose operations use heavy haul truck is interest to study how impacted AHS if will operated in Indonesia.

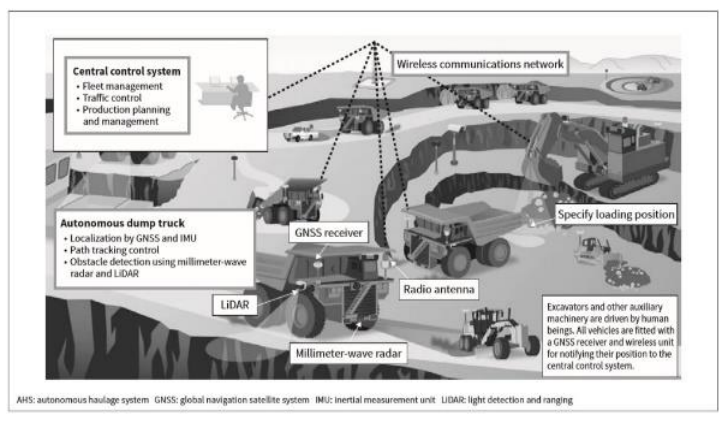

Fig. 1. Illustration AHS [3]

Operation of AHS in Indonesia by eliminating operators is suspected to affect the sustainability of mining operations. Currently, by using operators, mining companies contribute to increasing employment, influence regional economic growth and in the end, mining areas that were previously remote areas become areas that grow and develop.

Regarding this condition, study will focus on how impact of AHS operation in Indonesia open pit coal mining company.

\section{LITERATURE REVIEW \& RESEACH METHODOLOGY}

\section{A. Autonomous Haulage System}

Terminology Autonomous Haul System in this thesis is a system included personnel team, Autonomous kit at the dump truck, network infrastructure at field, software and allows dump truck to operate without operator. AHS development in mining was initiated by two major manufacturer, Komatsu, and Caterpillar (Fig. 2). 


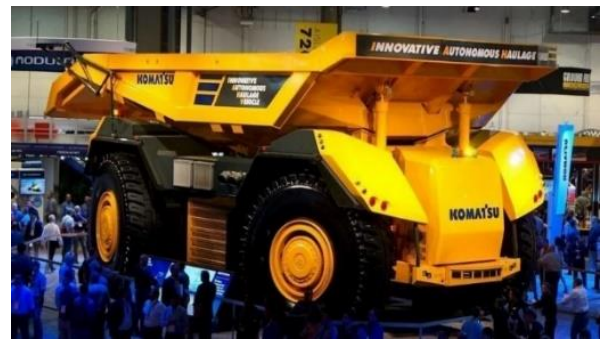

Fig. 2. Komatsu autonomous haul vehicle

Simulation operation in Lucy mine described AHS has improvement in [4]:

1. Fuel consumption decreases by $5.7 \%$ for liter/cycle or $6.7 \%$ for liter/ton

2. Increase lifetime of tire by $7.6 \%$ for $\mathrm{mm} /$ cycle

3. Production increase around $21.3 \%$ based on manual fleet, the increasing coming from eliminate rest time, shift change time etc.

4. Fleet at mining with a 9 manned truck can be reduce with AHS by 7 AHS.

5. Maintenance costs increase $4 \%$.

Related with benefit of AHS, also need additional cost for AHS. The additional cost of AHS is like additional kit at haul truck, network \& infrastructure for wifi at mine site, project management to deploy this system, etc. Additional cost AHS kit for CAT 793D is USD 1.000.000 and that mean for Manned truck CAT793D investment cost per unit is USD 4.000.000 and for CAT 793D with AHS Kit is USD 5.000.000. Additional cost for network \& infrastructure wifi is shown in Table 1 below:

TABLE I

NETWORK \& INFRASTRUCTURE AHS [4]

\begin{tabular}{|l|c|c|r|c|}
\hline \multicolumn{1}{|c|}{ Items } & Unit & Qty & \multicolumn{1}{c|}{ Price } & Total \\
\hline Basic Transmission Station & USD & 30 & 30.000 & 900.000 \\
\hline Servers (with redundancy) & USD & 8 & 12.500 & 100.000 \\
\hline Routes & USD & 10 & 40.000 & 400.000 \\
\hline Switches & USD & 20 & 5.000 & 100.000 \\
\hline $\begin{array}{l}\text { Energy System (with } \\
\text { Redundancy) }\end{array}$ & USD & 1 & 150.000 & 150.000 \\
\hline $\begin{array}{l}\text { Network Adaptation (Cables } \\
\text { CAT 6) }\end{array}$ & USD & 1 & 200.000 & 200.000 \\
\hline $\begin{array}{l}\text { Monitoring System (Camera, } \\
\text { Switch Specific, etc) }\end{array}$ & USD & 1 & 1.500 .000 & 1.500 .000 \\
\hline $\begin{array}{l}\text { Positioning System with } \\
\text { redundancy (DGPS, Antennas, } \\
\text { etc) }\end{array}$ & USD & 1 & 200.000 & 200.000 \\
\hline \multicolumn{1}{|c|}{ Total } & & $\mathbf{3 . 5 5 0 . 0 0 0}$ \\
\hline
\end{tabular}

\section{B. Previous Study}

Literature reviews start with discussed the cost and benefit implementation AHS in west Australia open pit mining. AHS in Australia has enough benefit due to very high cost of Australian mining operators and lowest productivity time [5]. The next review is research simulation AHS about increasing investment expenditure, productivity, and maintenance cost. Decreasing tire cost, fuel, man hour and etc are explained very well in this research [4].
This study using previous research with following list in the Table 2 .

TABLE II

PREVIOUS STUDY REFERENCE

\begin{tabular}{|c|c|c|}
\hline Author & $\begin{array}{l}\text { Assessme } \\
\text { nt } \\
\text { Method }\end{array}$ & Result \\
\hline $\begin{array}{l}\text { (Bellamy and } \\
\text { Pravica, 2011) [5] }\end{array}$ & $\begin{array}{l}\text { Cost } \\
\text { benefit } \\
\text { Analysis }\end{array}$ & $\begin{array}{l}\text { Assessing possibility AHS } \\
\text { implementation in Australian Open } \\
\text { Pit Mining }\end{array}$ \\
\hline $\begin{array}{l}\text { (Parreira, 2013) } \\
\text { [4] }\end{array}$ & $\begin{array}{l}\text { Simulatio } \\
\mathrm{n} \\
\text { Modelling }\end{array}$ & $\begin{array}{l}\text { Simulate mine haulage compare an } \\
\text { autonomous haulage system (AHS) } \\
\text { with one in which human drivers } \\
\text { operate the vehicles }\end{array}$ \\
\hline $\begin{array}{l}\text { (Brundrett, 2014) } \\
\text { [6] }\end{array}$ & $\begin{array}{l}\text { Cost } \\
\text { Benefit \& } \\
\text { Market } \\
\text { Analysis }\end{array}$ & $\begin{array}{l}\text { Commercialization of autonomous } \\
\text { vehicle technology in surface } \\
\text { mining operations }\end{array}$ \\
\hline $\begin{array}{l}\text { (Voronov, Voronov } \\
\text { and Makhambayev, } \\
\text { 2020) [2] }\end{array}$ & $\begin{array}{l}\text { Paper } \\
\text { Reference }\end{array}$ & $\begin{array}{l}\text { Current State and Development } \\
\text { Prospects of Autonomous Haulage } \\
\text { at Surface Mines }\end{array}$ \\
\hline $\begin{array}{l}\text { (Hardjana et al., } \\
\text { 2019) [7] }\end{array}$ & $\begin{array}{l}\text { RAPFISH } \\
\text { (Rapid } \\
\text { Appraisal } \\
\text { Fishery) }\end{array}$ & $\begin{array}{l}\text { Sustainability assessment in open } \\
\text { pit coal mining Indonesia with } \\
\text { dimension Ecology, Economy, } \\
\text { Socio Culture, Legal, Infrastructure } \\
\text { Technology }\end{array}$ \\
\hline Proposed & $\begin{array}{l}\text { RAPFISH } \\
\text { (Rapid } \\
\text { Appraisal } \\
\text { Fishery) }\end{array}$ & $\begin{array}{l}\text { Assessing possibility AHS } \\
\text { implementation sustainability } \\
\text { assessment with dimension } \\
\text { Ecology, Economy, Socio Culture, } \\
\text { Legal, Infrastructure Technology }\end{array}$ \\
\hline
\end{tabular}

Outlook and recent developments AHS described has potential development of AHS is still high, marked by the manufacturer to multiply, countries with lower per capita incomes are also applying AHS, and commodities that not only mineral mines [2]. The last literature review is related to mining conditions in Indonesia, where sustainability aspects need to be considered if a work system is changed, considering that currently open coal mining in Indonesia has a very strong impact on the ecology, economy, socio culture, legal, and infrastructure technology [7].

\section{Research Methodology}

Sustainability assessment for this research has six stages. First stage of this assessment is determined attribute of sustainability. Dimension of sustainability of open pit coal mining consist of Ecology, Economic, Socio culture, Legal and Technology infrastructure. Attribute and scoring for each dimension are determining by expert at open pit coal mining.

After completing the development of attributes and scores, research continued to expert interview of sustainability attribute which have long experience in open pit coal mining. The experts interviewed consisted of various experience including mining engineering operational, SHE and CSR mining Expert, mining project execution expert, heavy equipment product development for open pit coal mining expert, and business development mining expert. Detailed activity on sustainability assessment is represent in Fig. 3.

Data processing use a software RAPFISH (rapid appraisal for fishery) which is a rapid assessment technique 
that allows for multi-disciplinary assessments. In this case it was originally used to assess the sustainability status of a fishery developed by the University of British Columbia, Canada.

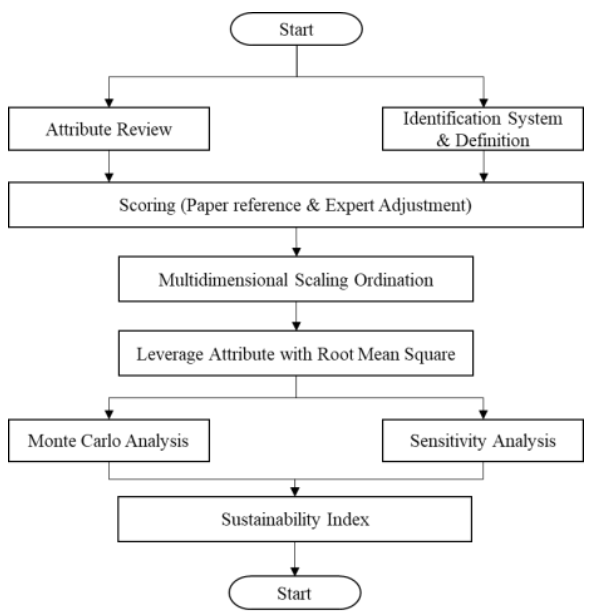

Fig. 3. Sustainability assessment framework

Output of RAPFISH is ordinance MDS (multidimensional scaling) of sustainability attribute for existing condition and object of research. The next step is analysis of leveraging score of sustainability attributes with a use root mean square and find an attribute can leverage of sustainability research object.

Final step is "Monte Carlo" analysis to determine the effect of errors in scoring. To determine the accuracy of the analysis, the determination of "Goodness of fit" in MDS was carried out based on the S-Stress value calculated from the $S$ and $R 2$ values. The iteration process can be stopped if the value of R2 is close to 1 . Low stress values indicate "good fit", and high S values indicate otherwise [8].

\section{RESULTS}

Expert for this research is chosen with experience from multi discipline, Senior business development in mining industry, Operational Mining Site Manager, Strategic Heavy Equipment Product Development, Project Manager at Mining Contractor company, Operational Research Manager, and SHE \& CSR Development expert. All of expert should be minimum pass "Pengawas Operational Madya" and have experience in all dimension of sustainability assessment.

\section{A. Ecology Assessment}

From the research result can be described in an ordinance RAPFISH that AHS and Manned have differences in Ecology dimension (see Fig 4). Index from AHS is higher than Manned with a number is 86,69 for AHS and manned is 64,09 , in scale range $0-100$. AHS is considered increase a sustainability index because some reason and can described in leverage attribute below:

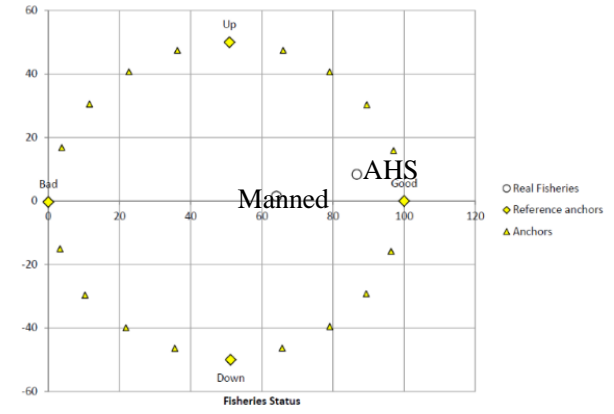

Fig. 4. Ordinance AHS vs manned in ecology dimension

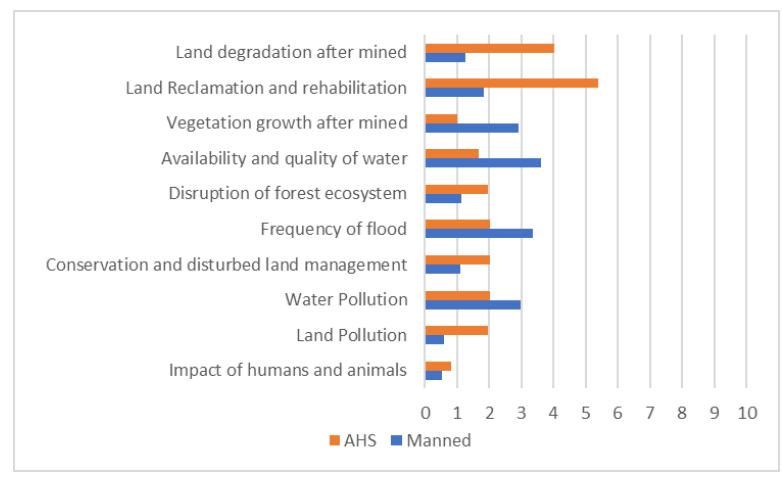

Fig. 5. Leverage attribute manned at ecology dimension

Fig 5. explained leverage factor in ecology dimension for manned haul truck and AHS, at least for manned haul truck leverage factor is related (1) vegetation growth after mined, (2) availability and quality of water, (3) frequency of flood and the last is (4) water pollution.

Leverage factor for AHS is focused at two attributes, (1) land degradation and (2) land reclamation \& rehabilitation (see Fig. 5). AHS is perceived to be able to increase the ecological impact in open pit mining due to the standard and strict AHS operating requirements so that it will directly make attributes that are manned haul truck ignored will be improved by mining companies.

\section{B. Economic Dimension Assessment}

Assessment in economic dimension for sustainability index AHS and Manned haul truck described is Manned have index 75.26 and AHS get it number 65.37 (see Fig. 6). Manned haul truck has a slightly higher compare in AHS in total but if digging more the one attribute increase and the others one is decrease. Attribute leverage in economic dimension shown in Fig 7.

Leverage factor for manned haul truck is from (1) post mining activities and (2) contribution to local GDP (see detail in Fig. 7). The same thing happened in AHS for two attributes in manned perceived, but for AHS the leverage factor increased including (1) company income and (2) economic value of ex-mining land (see detail in Fig. 7).

Post-mining economic activity and contribution to PDRB from the results of interviews and FGD are derived from the same problem where currently large mines in East 
Kalimantan and South Kalimantan are dominating the economic activities of the district. The expert stated that the contribution of coal mining in South Kalimantan to GDP is almost $46 \%$ and this is proven by statistical data from the BPS of Tanjung Tabalong Regency 2019. Distribution PDRB by business sector for Tanjung Tabalong regency is $41.86 \%$ from mining, Agriculture $11.01 \%$, trading sector and industry is same $8.9 \%$ and the rest is others [9].

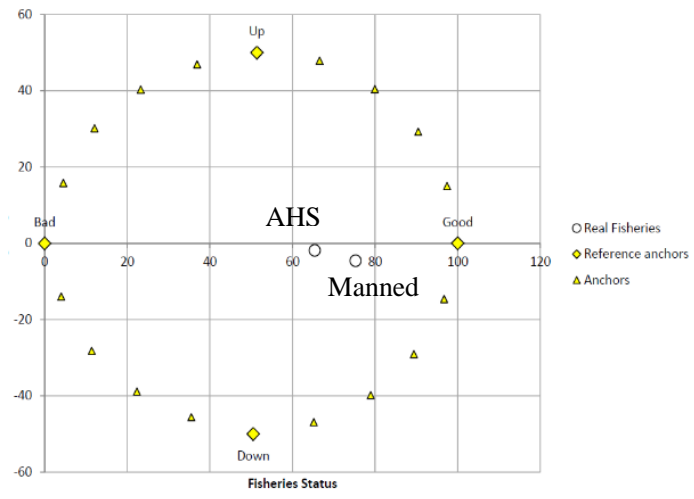

Fig. 6.Ordinance AHS vs manned in economy dimension

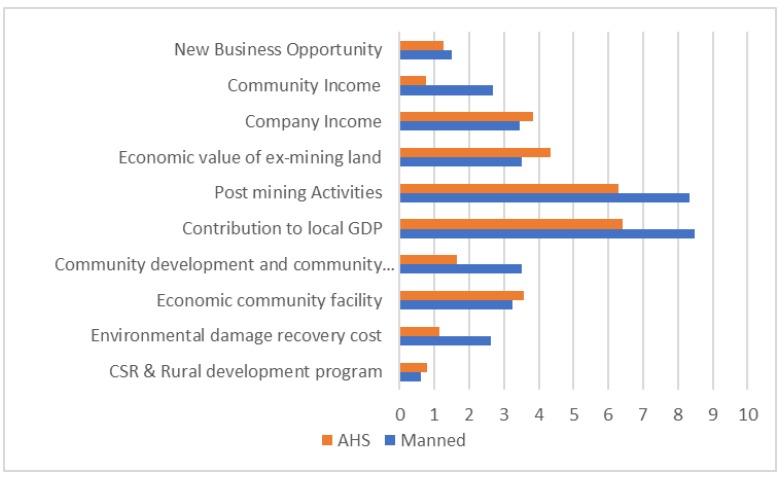

Fig. 7. Leverage attribute manned and AHS at economy dimension

With a very significant contribution, of course, this is good when the mining company is still operating, but if there are many changes, for example, the use of AHS is something that must be done to maintain national energy security, the mining company and together with all stakeholders need to think about from now were the direction of the regional economic activities in the future.

\section{Socio culture Dimension Assessment}

Analysis with MDS on this social dimension found that the sustainability index of the AHS for this dimension was lower than that of manned. His score was 68.82 for the manned and 58.74 for AHS (see Fig. 9).

When examined from each attribute using root mean square analysis, founded that manned has many factors that can be used as levers to increase its sustainability. AHS have less leverage factor this is an indicator that the perception of the expert that the problem to be resolved is focused on the (1) frequency of conflicts and (2) the influence of mining companies on existing values in socio-cultural.
The discussion regarding Fig. 10, at the end of the study was in the form of interviews with experts questioning the results of the leverage analysis where labor and public health factors got a smaller perception compared to the frequency of conflicts and the influence of community values on AHS. This is different from the condition of the leverage factor in the manned truck which is almost evenly distributed.

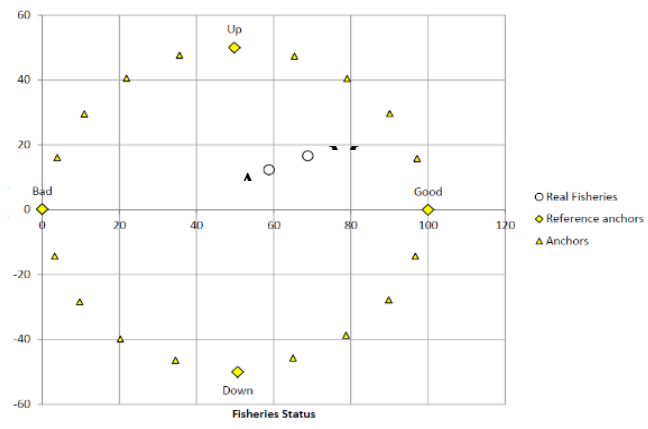

Fig. 8. Ordinance AHS vs manned in socio culture dimension

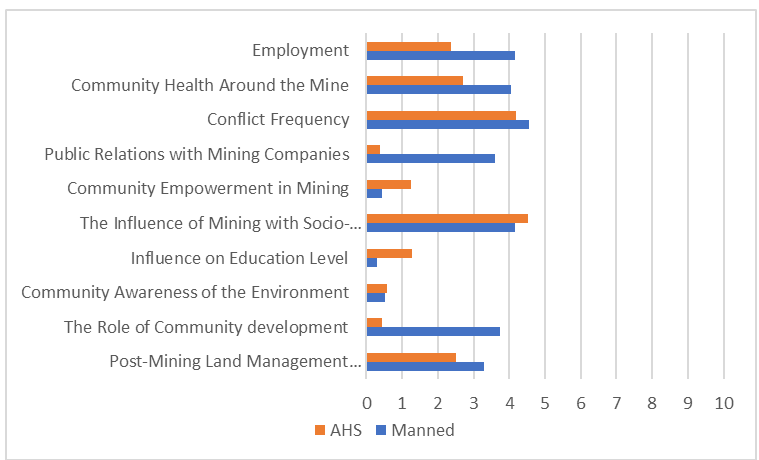

Fig. 9. Leverage attribute manned at socio culture dimension

The expert gave an understanding that the four leveraging factors had the same importance to the leveraging factors of sustainability from the social dimension, but because there was the use of AHS which resulted in a reduction in the number of employees working in mines, the attribute frequency of conflicts and changes in value in the community needed to be a first concern.

\section{Legal Dimension Assessment}

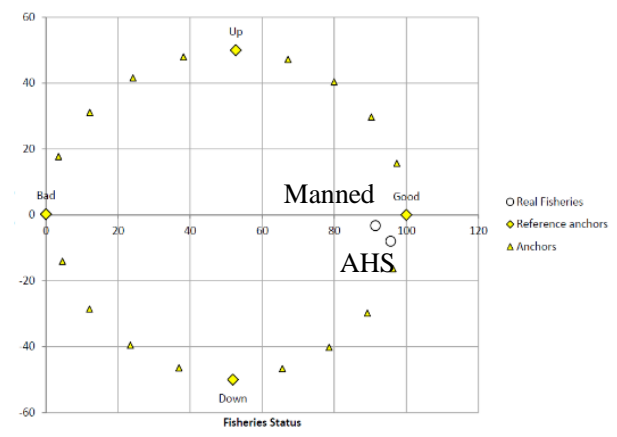

Fig. 10. Ordinance AHS vs manned in legal dimension 
The analysis of the sustainability of this legal dimension gets an almost similar perception between manned haul trucks and AHS. Apart from being almost like the score, the index is almost close to 100 , because this sustainability assessment was carried out on the perceptions of two large mines in East Kalimantan and South Kalimantan. where the mining commitment is very high in compliance with applicable laws (Fig. 11)

Legal dimension is not much can be discussed in this dimension given the perception that research is given to two large mines that have a reputation and adhere to high levels of laws and regulations.

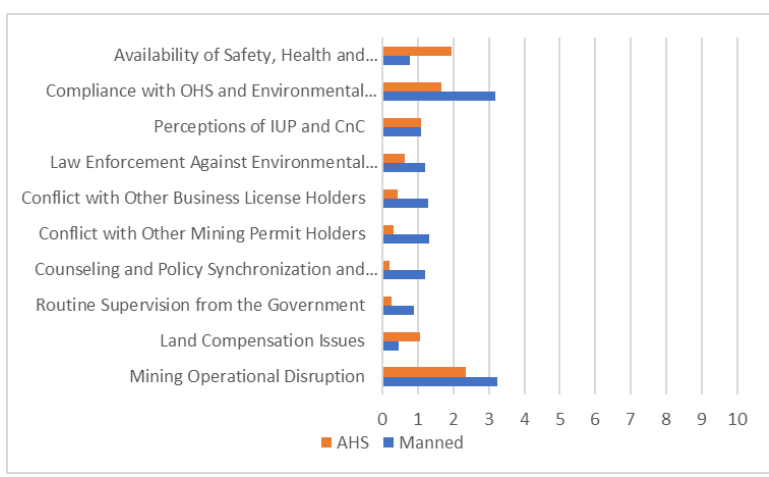

Fig. 11. Leverage attribute manned and AHS at legal dimension

\section{E. Technology \& Infrastructure Dimension Assessment}

The assessment of the sustainability of the technology and infrastructure dimensions found that AHS have a higher sustainability index compared to manned haul trucks. The score obtained by AHS was 87.12 while for the manned haul truck the score was 75.25 (Fig. 13).

Leverage attribute for manned truck in infrastructure \& technology dimension is (1) Nursery and revegetation technique and (2) post mining land use. In addition to the two attributes that are manned, there are also 3 attributes that are above average for other manned attributes, namely IPPKH land management techniques, existence of mining infrastructure, and pollution Impact control techniques (see detail Fig. 13).

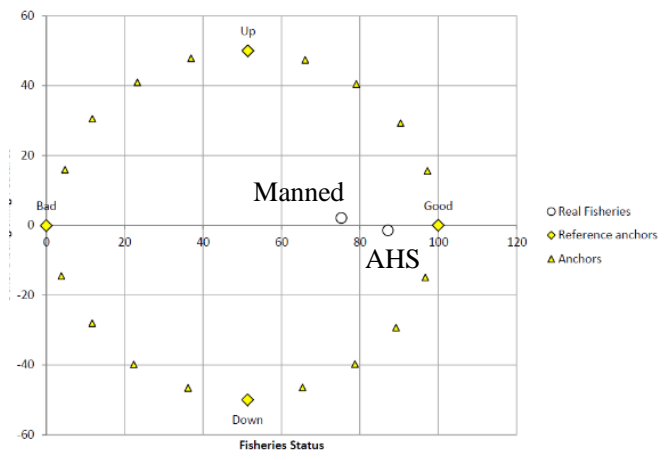

Fig. 12. Ordinance AHS vs manned in infrastructure and technology
As shown in Fig. 14, there are 2 factors that can increase the sustainability index, namely (1) complaint with SHE regulation and (2) Mining operational disruption, while for AHS the leveraging factor is mining operational disruption.

The results of the root mean square analysis show that of the 10 attributes that were assessed on AHS, 8 of them had a significant improvement. The two leveraging attributes are the same as those on the manned haul truck, namely (1) nursery and revegetation, as well as (2) cooperation between sectors in mining (Fig. 14).

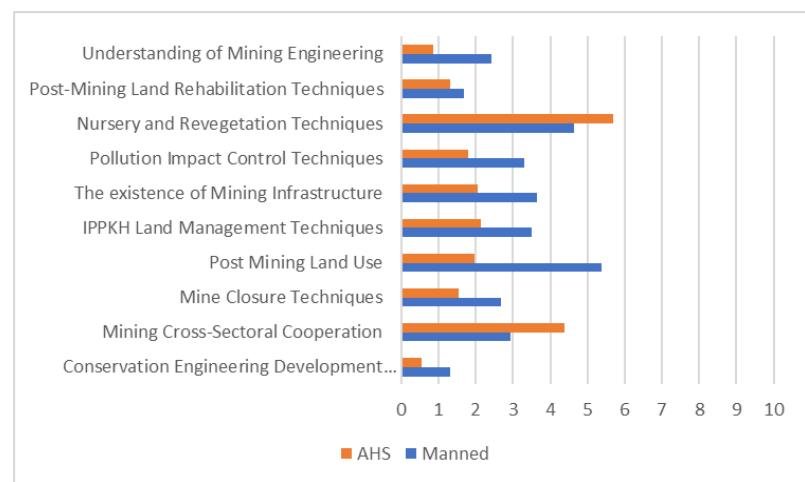

Fig. 11. Leverage attribute manned and AHS at infrastructure \& technology dimension

\section{F. Summary Sustainability Assessment}

The results of the manned sustainability assessment and AHS can be seen in the Fig. 14. AHS have an index of excellence in the ecological, legal and technology dimensions, while manned excels in the economic and socio-cultural dimensions. Indexing the five dimensions is found that AHS have an index of 78,712, while the manned haul truck has a lower index of 74,966 (Table 3). The two indexes when compared to the sustainability index [8], the manned haul trucks that are operated in two large mines in East Kalimantan and South Kalimantan have a "quite sustainable" status. while the use of AHS in both mines in East Kalimantan and Kalimantan received a status "sustainable".

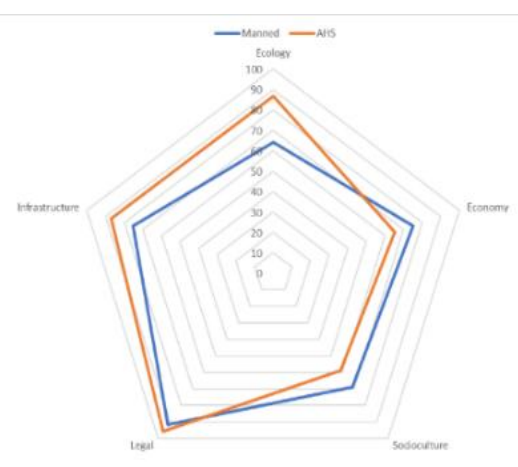

Fig. 14. Kite diagram sustainability index manned and AHS

"Monte Carlo" analysis with a 95\% confidence level obtained results below the $5 \%$ tolerance limit, as shown in 
the Table 3, That mean MDS analysis in this research can be trusted.

The analysis results show the value of "S-Stress", both in each dimension and multidimensional have a smaller value than the provisions $(<0.25)$, the smaller than 0.25 the better (Table 4). While the Coefficient of Determination (R2) is at every dimension and multidimensional is quite high (close to 1), thus the two statistical parameters indicate that all the attributes used in each dimension are sufficient to explain the sustainability of the open pit coal mining.

TABLE III

SUMMARY (MDS VS MONTE CARLO ANALYSIS)

\begin{tabular}{|c|c|c|c|c|c|c|}
\hline \multirow{2}{*}{} & \multicolumn{2}{|c|}{ Manned } & \multicolumn{2}{c|}{ AHS } & Manned & AHS \\
\cline { 2 - 7 } & MDS & $\begin{array}{c}\text { Monte } \\
\text { carlo }\end{array}$ & MDS & $\begin{array}{c}\text { Monte } \\
\text { carlo }\end{array}$ & Delta & Delta \\
\hline Ecology & 64,09 & 63,2 & 86,69 & 84,12 & 0,89 & 2,57 \\
\hline Economy & 75,26 & 73,9 & 65,37 & 63,81 & 1,36 & 1,56 \\
\hline Socio culture & 68,82 & 67,73 & 58,74 & 58,08 & 1,09 & 0,66 \\
\hline Legal & 91,41 & 88,81 & 95,64 & 92,34 & 2,6 & 3,3 \\
\hline Infrastructure & 75,25 & 72,84 & 87,12 & 84,32 & 2,41 & 2,8 \\
\hline & 74,966 & 73,296 & 78,712 & 76,534 & 1,67 & 2,178 \\
\hline
\end{tabular}

TABLE IV

STRESS VALUE \& R-SQUARED

\begin{tabular}{|c|c|c|c|c|c|}
\hline & Ecology & Economy & $\begin{array}{c}\text { Socio } \\
\text { culture }\end{array}$ & Legal & Infrastructure \\
\hline $\begin{array}{c}\text { Stress } \\
\text { Value }\end{array}$ & 0,145 & 0,134 & 0,142 & 0,133 & 0,131 \\
\hline $\begin{array}{c}\text { R- } \\
\text { Squared }\end{array}$ & 0,952 & 0,947 & 0,952 & 0,956 & 0,954 \\
\hline
\end{tabular}

\section{CONCLUSION AND RECOMMENDATION}

\section{A. Conclusion}

AHS will affect with slightly higher sustainability index than manned haul trucks, AHS sustainability index is 78,712 and manned haul truck is 74,966. Detail see Table 4.

\section{B. Recommendation}

To the attributes that become leverage factors should be done further analysis to be mapped the potential activities that can be done as what, so that it can be evaluated additional costs and so on to affect the owning and operating cost of the AHS.

\section{ACKNOWLEDGMENT}

I Would like to thank to Dr. Ir. Gembong Baskoro, M.Sc, and Dr. Eka Budiarto, S.T., M.Sc., Dena Hendriana, B.Sc., S.M., Sc.D., Dr. Ir. Henry Nasution and all Lecturers who have guided me while studying in Swiss German University. And, to Mr. Edhie Sarwono, Mr. Yo. Eka Prayuda, and Mr. Bayu Cahyono who have advising me while studying in Swiss German University.

\section{REFERENCES}

[1] Y. A. N. Kardana, et al., Fuel Level Monitoring and Security Warning Tools using IoT for Komatsu Excavator PC200-8M0, 2020.

[2] Y. Voronov, A. Voronov, and D. Makhambayev, "Current State and Development Prospects of Autonomous Haulage at Surface Mines", E3S Web of Conferences, 174, pp. 1-7, 2020. doi: $10.1051 / \mathrm{e} 3$ sconf/202017401028.

[3] T. Hamada and S. Saito, "Autonomous driving technology for connected cars", Hitachi Review, 67 (1), pp. 87-91, 2018. Available

https://www.hitachi.com/rev/archive/2018/r2018_01/pdf/P087_ 092_R1a07.pdf.

[4] J. Parreira, An Interactive Simulation Model to Compare an Autonomous Haulage Truck System with a Manually-Operated System, Thesis, 2013.

[5] D. Bellamy and L. Pravica, "Assessing the impact of driverless hau trucks in Australian surface mining", Resources Policy, 36 (2), pp. 149-158, 2011. doi: 10.1016/j.resourpol.2010.09.002.

[6] S. Brundrett, Industry Analysis of Autonomous Mine Haul Truck Commercialization, pp. 1-2, 2014.

[7] A. K. Hardjana, "Analisis nilai keberlanjutan pengelolaan bentang alam pasca tambang batubara pada areal izin pinjam pakai kawasan hutan", Jurnal Teknologi Mineral dan Batubara, 15 (3), pp. 159177, 2019. doi: 10.30556/jtmb.vol15.no3.2019.1008.

[8] R. Nurmalina, "Keberlanjutan sistem ketersediaan beras nasional : pendekatan teknik ordinasi rap-rice dengan metoda multidimensional scaling (MDS)", Jurnal Agribisnis dan Ekonomi Pertanian, 2 (2), pp. 65-88, 2008.

[9] BPS Tanjung Tabalong, Statistik Daerah, 2020. 